\title{
Cerebellar ataxia as a presenting symptom in a patient with anti-NMDA receptor encephalitis
}

Michiel H.F. Poorthuis, MD, Josephus L.M. van Rooij, MD, Anna H. Koch, MD, Annelies E.M. Verdonkschot, MD, Machteld M. Leembruggen, MD, PhD, and Maarten J. Titulaer, MD, PhD

Neurol Neuroimmunol Neuroinflamm 2019;6:e579. doi:10.1212/NXI.0000000000000579

Anti-NMDA receptor (anti-NMDAR) encephalitis is a treatment-responsive autoimmune encephalitis, first described in 2007. ${ }^{1}$ Ovarian teratomas are found in one-third of the patients. ${ }^{2}$ The clinical features of this disorder vary between patients and age groups and usually include abnormal (psychiatric) behavior or cognitive dysfunction, speech dysfunction (pressured speech, verbal reduction, and mutism), seizures, movement disorders, dyskinesias, or rigidity/abnormal postures, decreased level of consciousness, autonomic dysfunction, or central hypoventilation. ${ }^{2}$ Cerebellar ataxia has been described as a symptom during the first months of the disease, especially in young children, in combination with other symptoms. ${ }^{2,3}$ It is extremely rare as the initial symptom, especially in adults. We report a case of a female adult with anti-NMDAR encephalitis presenting with cerebellar ataxia associated with recurrent mature ovarian teratomas.

\section{Case report}

A 32-year-old woman, born in South Korea and adopted at age 4 months, presented with vertigo, nausea, and vomiting for 4 days. Her medical history consisted of bilateral cystectomy revealing mature teratomas, discovered by ultrasound examination after a missed abortion at age 26 years. During cesarean sections afterward (ages 29 and 31 years), no macroscopic abnormalities were seen. Furthermore, she had had depressive symptoms, treated with venlafaxine for years.

Neurologic examination showed a horizontal gaze-evoked nystagmus to the right without other neurologic signs or symptoms. Laboratory investigations on admission were normal, and brain CT showed no abnormalities.

Initially, she improved after treatment with antiemetic drugs, but after 3 days, she deteriorated quickly, also complaining of headache. Neurologic examination showed nystagmus in all directions and dysarthric speech (cerebellar) that further worsened to impaired speech restricted to one-word sentences. She showed bilateral dysmetria of the lower and especially the upper limbs, truncal ataxia, and inability to stand and walk. Psychiatric evaluation showed rapid progression of depressive symptoms with suicidal ideation and labile affect.

Brain MRI and MRV were normal. CSF analysis and extensive laboratory investigations showed pleocytosis (table). Anti-NMDAR antibodies were negative in serum, but positive in CSF, ${ }^{4}$ confirming the diagnosis of definite anti-NMDAR encephalitis. ${ }^{3}$

The patient was treated with IV methylprednisolone 1,000 $\mathrm{mg}$ (day 13, 5 days) and IV immunoglobulins $0.4 \mathrm{~g} / \mathrm{kg}$ (day 16, 5 days). Thorax/abdomen CT and transvaginal ultrasound revealed 2 lesions in the pelvic area with fat tissue and calcifications, suspect for teratomas. Bilateral laparotomic ovariectomy was performed (day 19). Pathologic examination showed mature cystic
Correspondence

Dr. Titulaer

m.titulaer@erasmusmc.nl

From the Department of Neurology (M.H.F.P., J.L.M.R., M.M.L.) and Department of Gynaecology (A.H.K., A.E.M.V.), Tergooi, Blaricum; and Department of Neurology (M.J.T.), Erasmus MC, Rotterdam, The Netherlands.

Go to Neurology.org/NN for full disclosures. Funding information is provided the end of the article.

Informed consent: The patient gave informed consent.

The Article Processing Charge was funded by the authors.

This is an open access article distributed under the terms of the Creative Commons Attribution-NonCommercial-NoDerivatives License 4.0 (CC BY-NC-ND), which permits downloading and sharing the work provided it is properly cited. The work cannot be changed in any way or used commercially without permission from the journal. 
Table Overview of investigations

\begin{tabular}{|c|c|}
\hline \multicolumn{2}{|l|}{ CSF analysis } \\
\hline White blood cells & $\begin{array}{l}30 \times 10^{6} / \mathrm{L}(100 \% \text { mononuclear cells }) \\
{\left[\text { ref: }<5 \times 10^{6} / \mathrm{L}\right]}\end{array}$ \\
\hline Protein & 31 [ref: 24-49] mg/dL \\
\hline Glucose & 3.6 [serum: 6.4$] \mathrm{mmol} / \mathrm{L}$ \\
\hline Erythrocytes & $<5,000 \times 10^{6} / \mathrm{L}$ \\
\hline Oligoclonal bands & Present \\
\hline IgG index & 0.59 \\
\hline IgG quotient & 3.1 [ref: <2.8] \\
\hline \multicolumn{2}{|l|}{ PCR in liquor } \\
\hline HSV-1, HSV-2, VZV, EBV, enteroviruses, parechoviruses, and Borrelia & Negative \\
\hline \multicolumn{2}{|l|}{ Extensive laboratory investigations, among these: } \\
\hline TSH, anti-TPO, and vitamin E & Normal \\
\hline Ceruloplasmin, anti-tissue transglutaminase, anti-endomysium, and anti-GQ1b & Negative \\
\hline \multicolumn{2}{|l|}{ Antibodies in serum and CSF } \\
\hline Anti-NMDAR in serum & Negative \\
\hline Anti-NMDAR in CSF (cell-based assay and immunohistochemistry) & Positive \\
\hline $\begin{array}{l}\text { Anti-Hu, anti-Yo, anti-Ri, anti-Tr, anti-amphiphysine, anti-CV2 (CRMP5), anti-Ma1, anti-Ma2, anti-GAD65, } \\
\text { anti-LGII, anti-Caspr2, anti-GABA }{ }_{B} R \text {, anti-GABA }{ }_{A} R \text {, anti-AMPAR, and anti-DPPX }\end{array}$ & Negative \\
\hline \multicolumn{2}{|l|}{ Urine analysis } \\
\hline Dipstick test and pregnancy test & Negative \\
\hline
\end{tabular}

Abbreviations: anti-NMDAR = anti-NMDA receptor; anti-TPO = anti-thyroid peroxidase; EBV = Epstein-Barr virus; $\mathrm{HSV}=$ herpes simplex virus; $\mathrm{TSH}=$ thyroidstimulating hormone; VZV = varicella zoster virus.

Abnormal values are shown in italic font.

teratomas, without immature components, containing nervous tissue. Hormone replacement therapy was started.

Her neurologic condition improved within a week, but the depressive mood remained. Recovery was hampered by urosepsis, treated with cefuroxime/amoxicillin. She was treated with a second course of methylprednisolone 4 weeks after the initial treatment and immunoglobulins at 8 weeks for remaining speech impairments and severe depression. This resulted in further improvement of both. After 6 weeks, the patient was transferred to a rehabilitation unit.

After 6 months, the patient returned home. She was able to perform activities of daily living independently, but needed walking aids outside due to residual ataxia and had not returned to work (yet).

\section{Discussion}

This case with cerebellar ataxia as an initial symptom highlights an unusual presentation of anti-NMDAR encephalitis. If cerebellar ataxia is present in patients with anti-NMDAR encephalitis, it is almost exclusively found in (young) children, and most frequently, it appears later in the disease in combination with other symptoms. ${ }^{2}$ Different brainstemcerebellar symptoms have been described, such as opsoclonus-myoclonus syndrome, ocular movement abnormalities, and low cranial nerve involvement in patients with ovarian teratomas, but these symptoms have more frequently been described in whom no NMDAR antibodies could be identified. ${ }^{5}$ Although 2 simultaneously occurring paraneoplastic neurologic syndromes, due to an ovarian teratoma, cannot be fully excluded, this is considered unlikely. The development of multiple symptoms quickly into diseases compatible with anti-NMDAR encephalitis (psychiatric symptoms and mutism), the confirmation of NMDAR antibodies by different tests, ${ }^{4}$ and the identification of an ovarian teratoma are suitable with a diagnosis of "definite antiNMDAR encephalitis."3

Although it is known that anti-NMDAR IgG antibodies bind to granular cells in the cerebellum (but not to Purkinje cells), ${ }^{6}$ it is unknown why only approximately $5 \%$ of patients show cerebellar complaints. MRI abnormalities of the cerebellum have been described in $6 \%$ of patients. ${ }^{7}$ A small study showed 
progressive cerebellar atrophy by follow-up MRI in 2 of 15 patients with anti-NMDAR encephalitis. ${ }^{6}$

In conclusion, cerebellar ataxia is unusual in adult patients and an extremely rare presenting symptom of anti-NMDAR encephalitis. This case shows that anti-NMDAR encephalitis should be considered in the differential diagnosis of cerebellar ataxia, especially in patients with previous teratomas and those developing other symptoms shortly afterward.

\section{Acknowledgment}

The authors thank J.J. Oudejans, pathologist, Tergooi, Blaricum, The Netherlands, and C.E. de Boer, physiatrist, Tergooi, Blaricum, The Netherlands, for their advice on this case.

\section{Study funding}

No targeted funding reported.

\section{Disclosure}

M.J. Titulaer has filed a patent for methods for typing neurological disorders and cancer, and devices for use therein, and has received research funds for serving on a scientific advisory board of MedImmune LLC, for consultation at Guidepoint Global LLC, for teaching courses by Novartis, and an unrestricted research grant from Euroimmun AG. M.J. Titulaer has received funding from the Netherlands Organization for Scientific Research (NWO, Veni incentive), from the Dutch Epilepsy Foundation (NEF, project 14-19), and from ZonMw (Memorabel program). The other authors report no conflicts of interest. Go to Neurology.org/NN for full disclosures.

\section{Publication history}

Received by Neurology: Neuroimmunology \& Neuroinflammation January 3, 2019. Accepted in final form April 21, 2019.

Appendix Authors

\begin{tabular}{|c|c|c|c|}
\hline Name & Location & Role & Contribution \\
\hline $\begin{array}{l}\text { Michiel H.F. } \\
\text { Poorthuis, MD }\end{array}$ & $\begin{array}{l}\text { Department of } \\
\text { Neurology, } \\
\text { Tergooi, Blaricum, } \\
\text { The Netherlands }\end{array}$ & Author & $\begin{array}{l}\text { Conception and } \\
\text { design, acquisition of } \\
\text { data or analysis and } \\
\text { interpretation of } \\
\text { data, wrote the first } \\
\text { draft of the } \\
\text { manuscript, and } \\
\text { approved the final } \\
\text { version for } \\
\text { publication }\end{array}$ \\
\hline $\begin{array}{l}\text { Josephus L.M. } \\
\text { van Rooij, MD }\end{array}$ & $\begin{array}{l}\text { Department of } \\
\text { Neurology, } \\
\text { Tergooi, Blaricum, } \\
\text { The Netherlands }\end{array}$ & Author & $\begin{array}{l}\text { Conception and } \\
\text { design, acquisition of } \\
\text { data or analysis and } \\
\text { interpretation of } \\
\text { data, wrote the first } \\
\text { draft of the } \\
\text { manuscript, and } \\
\text { approved the final } \\
\text { version for } \\
\text { publication }\end{array}$ \\
\hline
\end{tabular}

Appendix (continued)

\begin{tabular}{|c|c|c|c|}
\hline Name & Location & Role & Contribution \\
\hline $\begin{array}{l}\text { Anna H. Koch, } \\
\text { MD }\end{array}$ & $\begin{array}{l}\text { Department of } \\
\text { Gynaecology, } \\
\text { Tergooi, Blaricum, } \\
\text { The Netherlands. }\end{array}$ & Author & $\begin{array}{l}\text { Conception and } \\
\text { design, acquisition of } \\
\text { data or analysis and } \\
\text { interpretation of } \\
\text { data, wrote the first } \\
\text { draft of the } \\
\text { manuscript, and } \\
\text { approved the final } \\
\text { version for } \\
\text { publication }\end{array}$ \\
\hline $\begin{array}{l}\text { Annelies E.M. } \\
\text { Verdonkschot, } \\
\text { MD }\end{array}$ & $\begin{array}{l}\text { Department of } \\
\text { Gynaecology, } \\
\text { Tergooi, Blaricum, } \\
\text { The Netherlands. }\end{array}$ & Author & $\begin{array}{l}\text { Conception and } \\
\text { design, acquisition of } \\
\text { data or analysis and } \\
\text { interpretation of } \\
\text { data, revised the } \\
\text { manuscript critically } \\
\text { for important } \\
\text { intellectual content, } \\
\text { and approved the } \\
\text { final version for } \\
\text { publication }\end{array}$ \\
\hline $\begin{array}{l}\text { Machteld M. } \\
\text { Leembruggen, } \\
\text { MD, PhD }\end{array}$ & $\begin{array}{l}\text { Department of } \\
\text { Neurology, } \\
\text { Tergooi, Blaricum, } \\
\text { The Netherlands }\end{array}$ & Author & $\begin{array}{l}\text { Conception and } \\
\text { design, acquisition of } \\
\text { data or analysis and } \\
\text { interpretation of } \\
\text { data, revised the } \\
\text { manuscript critically } \\
\text { for important } \\
\text { intellectual content, } \\
\text { and approved the } \\
\text { final version for } \\
\text { publication }\end{array}$ \\
\hline $\begin{array}{l}\text { Maarten J. } \\
\text { Titulaer, MD, } \\
\text { PhD }\end{array}$ & $\begin{array}{l}\text { Department of } \\
\text { Neurology, } \\
\text { Erasmus MC, } \\
\text { Rotterdam, The } \\
\text { Netherlands }\end{array}$ & Author & $\begin{array}{l}\text { Conception and } \\
\text { design, acquisition of } \\
\text { data or analysis and } \\
\text { interpretation of } \\
\text { data, revised the } \\
\text { manuscript critically } \\
\text { for important } \\
\text { intellectual content, } \\
\text { and approved the } \\
\text { final version for } \\
\text { publication }\end{array}$ \\
\hline
\end{tabular}

\section{References}

1. Dalmau J, Tuzun E, Wu HY, et al. Paraneoplastic anti-N-methyl-D-aspartate receptor encephalitis associated with ovarian teratoma. Ann Neurol 2007;61:25-36.

2. Titulaer MJ, McCracken L, Gabilondo I, et al. Treatment and prognostic factors for long-term outcome in patients with anti-NMDA receptor encephalitis: an observational cohort study. Lancet Neurol 2013;12:157-165.

3. Graus F, Titulaer MJ, Balu R, et al. A clinical approach to diagnosis of autoimmune encephalitis. Lancet Neurol 2016;15:391-404.

4. Gresa-Arribas N, Titulaer MJ, Torrents A, et al. Antibody titres at diagnosis and during follow-up of anti-NMDA receptor encephalitis: a retrospective study. Lancet Neurol 2014;13:167-177.

5. Armangue T, Titulaer MJ, Sabater L, et al. A novel treatment-responsive encephalitis with frequent opsoclonus and teratoma. Ann Neurol 2014;75:435-441.

6. Iizuka T, Kaneko J, Tominaga N, et al. Association of progressive cerebellar atrophy with long-term outcome in patients with anti-N-Methyl-d-Aspartate receptor encephalitis. JAMA Neurol 2016;73:706-713.

7. Dalmau J, Gleichman AJ, Hughes EG, et al. Anti-NMDA-receptor encephalitis: case series and analysis of the effects of antibodies. Lancet Neurol 2008;7:1091-1098. 


\section{Neurology \\ Neuroimmunology \& Neuroinflammation}

\section{Cerebellar ataxia as a presenting symptom in a patient with anti-NMDA receptor encephalitis \\ Michiel H.F. Poorthuis, Josephus L.M. van Rooij, Anna H. Koch, et al. \\ Neurol Neuroimmunol Neuroinflamm 2019;6; \\ DOI 10.1212/NXI.0000000000000579}

This information is current as of June 4, 2019

Updated Information \&

Services

References

Citations

Subspecialty Collections

Permissions \& Licensing

Reprints including high resolution figures, can be found at:

http://nn.neurology.org/content/6/4/e579.full.html

This article cites 7 articles, 0 of which you can access for free at: http://nn.neurology.org/content/6/4/e579.full.html\#\#ref-list-1

This article has been cited by 1 HighWire-hosted articles: http://nn.neurology.org/content/6/4/e579.full.html\#\#otherarticles

This article, along with others on similar topics, appears in the following collection(s):

Autoimmune diseases

http://nn.neurology.org//cgi/collection/autoimmune_diseases Encephalitis

http://nn.neurology.org//cgi/collection/encephalitis

Paraneoplastic syndrome

http://nn.neurology.org//cgi/collection/paraneoplastic_syndrome

Information about reproducing this article in parts (figures,tables) or in its entirety can be found online at:

http://nn.neurology.org/misc/about.xhtml\#permissions

Information about ordering reprints can be found online:

http://nn.neurology.org/misc/addir.xhtml\#reprintsus

Neurol Neuroimmunol Neuroinflamm is an official journal of the American Academy of Neurology.

Published since April 2014, it is an open-access, online-only, continuous publication journal. Copyright

Copyright (C) 2019 The Author(s). Published by Wolters Kluwer Health, Inc. on behalf of the American

Academy of Neurology.. All rights reserved. Online ISSN: 2332-7812.

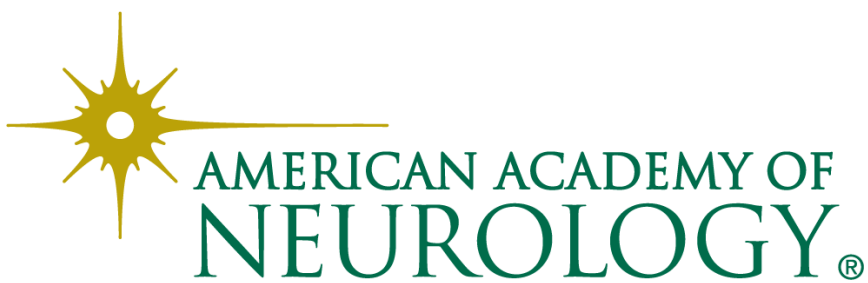

